\title{
En mann i 50-årene med elektrisk storm etter hjerteinfarkt
}

\author{
En mann i 50-årene uten tidligere hjertesykdom ble innlagt med akutt \\ hjerteinfarkt. Det videre forløpet var komplisert og krevde avansert \\ behandling.
}

Pasienten ble innlagt i lokalsykehus etter at han $i$ en uke hadde hatt flere episoder med press i brystet og ledsagende dyspné. Innleggelsesdagen fikk han akutte, vedvarende brystsmerter. Han var døv, men hadde for øvrig god helse og ingen kjent hjertesykdom. Ved ankomst til lokalsykehuset var han smertepåvirket. Det ble tatt et EKG, som viste sinusrytme, inkomplett høyre grenblokk og ST-elevasjon på 2-3 mm i avledningene V1-V3.

Det ble gitt trombolytisk behandling (tenecteplase) etter protokoll, og etter en time var pasienten smertefri. EKG var imidlertid uendret, med vedvarende ST-elevasjon. Rytmeovervåking viste hyppige ventrikulære ekstrasystoler og flere korte løp med ventrikkeltakykardi. Det oppsto også en episode med vedvarende ventrikkeltakykardi, som krevde elektrokonvertering. Man mistenkte manglende reperfusjon, og pasienten ble derfor fløyet til nærmeste universitetssykehus for redningsangioplastikk (rescue-PCI).

Hjerteinfarkt med ST-elevasjon i EKG skyldes nesten alltid trombotisk okklusjon av en epikardial koronararterie. Ved hjerteinfarkt med ST-elevasjon (STEMI) er den primære behandlingen rettet mot så rask reperfusjon som mulig. Dette kan oppnås ved trombolytisk behandling eller ved primær perkutan koronar intervensjon (primær PCI). Transporttid til nærmeste PCI-senter avgjør valg av behandling. Hvis man ikke kan få gjort primær perkutan koronar intervensjon innen 120 minutter, anbefales trombolytisk behandling (1). Ved utbredte EKG-forandringer og kort sykehistorie, definert som $<2 \mathrm{t}$, er dette tidskravet skjerpet til 90 minutter (1).

Tilbakegang av smerter og EKG-forandringer er tegn på vellykket trombolytisk behandling, og mer enn $50 \%$ reduksjon av STelevasjonen i den avledningen hvor denne var mest uttalt, tyder på reperfusjon (1).Ved manglende tegn på reperfusjon etter 45-60 minutter er det indikasjon for redningsangioplastikk. Omtrent $30 \%$ av dem som får trombolytisk behandling vil trenge dette (2). Hos vår pasient var det klar indikasjon for redningsangioplastikk. Det var vedvarende ST-elevasjon i EKG og de residiverende ventrikulære arytmiene forsterket mistanken om pågående iskemi.
Umiddelbart etter ankomst til universitetssykehuset ble pasienten tatt til angiografilaboratoriet. Koronar angiografi viste trekarssykdom med stenose proksimalt $i$ fremre nedadstigende gren av venstre koronararterie ( $L A D$ ), stenose på en marginalgren fra ramus circumflexus og flere stenoser i høyre koronararterie (fig 1). LAD-stenosen $i$ ble ansett å ligge bak symptomene (være «culprit»-lesjonen), og det ble der gjort perkutan koronar intervensjon med implantasjon av konvensjonell metallstent med godt angiografisk resultat.

I tillegg til stenosen i fremre nedadstigende gren av venstre koronararterie, som sannsynligvis hadde forårsaket infarktet, hadde pasienten omfattende koronarsykdom. Det anbefales imidlertid ikke å behandle andre lesjoner enn «culprit»-lesjonen i den akutte fasen (1). Hvis det er indikasjon for å behandle øvrige stenoser, gjøres dette senere. Unntaket er ved kardiogent sjokk, hvor det tilstrebes så fullstendig revaskularisering som mulig allerede i akuttfasen (1).

Ekkokardiografi utført umiddelbart etter ankomst viste en infarktskadet venstre ventrikkel med en ejeksjonsfraksjon på $30 \%$ (normalverdi > 50\%). Ingen mekaniske komplikasjoner eller klaffefeil av betydning ble påvist.

Kort tid etter utført perkutan koronar intervensjon oppsto det tre episoder med ventrikkelflimmer. De ble vellykket defibrillert, og ved etablering av egenrytme våknet pasienten umiddelbart. På hjerteovervåkingen fikk han samme kveld gjentatte episoder med polymorf ventrikkeltakykardi, og det var behov for ytterligere elektrokonverteringer. I forsøk på rytmestabilisering ble det gitt medikamenter i form av seloken, amiodaron og magnesiuminfusjon, men disse hadde ingen effekt. Det hadde utviklet seg en refraktær elektrisk storm. Pasienten ble derfor sedert og lagt i respirator.

«Elektrisk storm» defineres som mer enn tre vedvarende episoder med ventrikkeltakykardi, ventrikkelflimmer eller støt med defibrillator (ICD) i løpet av 24 timer (3). Mortaliteten er høy. Effektiv behandling

\author{
Stian Ross \\ stian.ross@so-hf.no \\ Ole Rossvoll \\ Marcel Moufack \\ Klinikk for hjertemedisin \\ St. Olavs hospital
}

\section{Rune Wiseth}

Klinikk for hjertemedisin

St. Olavs hospital

og

Institutt for sirkulasjon og bildediagnostikk

Norges teknisk-naturvitenskapelige universitet

Se kommentar på side 1606

Engelsk oversettelse på www.tidsskriftet.no 
krever forståelse av underliggende mekanisme og terapeutiske muligheter.

Ventrikkeltakykardi kan være monomorf eller polymorf. Ved monomorf ventrikkeltakykardi er alle QRS-kompleksene like. Monomorf ventrikkeltakykardi er som regel forbundet med et anatomisk patologisk substrat i ventrikkelen, som oftest et arrområde etter tidligere hjerteinfarkt. Aktiv iskemi er vanligvis ikke underliggende årsak, og monomorf vedvarende ventrikkeltakykardi er uvanlig i forløpet av et hjerteinfarkt (4).

Vår pasient, derimot, hadde residiverende episoder med polymorf ventrikkeltakykardi (QRS-komplekser med varierende mellomrom og utseende) og ventrikkelflimmer. Disse arytmiformene ses ofte i tidlig fase av akutt hjerteinfarkt, ved vedvarende iskemi (ved pågående infarsering) samt ved lang QT-tid. Den initiale behandlingen er rettet mot rask korrigering av iskemi, dekompensert hjertesvikt, elektrolyttforstyrrelser og andre underliggende årsaker. Hos de fleste kan man forhindre gjentatte takykardier med intravenøs behandling med betablokker og/ eller amiodaron (3).

Dersom revaskularisering og medikamentell behandling ikke har ønsket effekt, vil sedering erfaringsmessig ofte føre til at situasjonen roer seg. Man tror dette skyldes lavere adrenerg stimulering (5). I tillegg er det en fordel at pasienten er sedert i fall det skulle bli behov for multiple elektrokonverteringer.

Etter sedering og oppstart av respiratorbehandling ble situasjonen umiddelbart stabil. Det var da gått fire timer siden overflyttingen fra lokalsykehuset, og pasienten hadde stabil rytme de neste timene. Han var imidlertid hypotensiv, og det ble $i$ denne perioden anlagt aortaballongpumpe.

Behandling av maligne arytmier kan være indikasjon for innleggelse av aortaballongpumpe eller annen mekanisk sirkulasjonsstøtte $(6,7)$. Dette kan bedre koronar perfusjon, redusere hjertets motstand mot tømming av hjertet i systole (afterload) og også redusere behovet for proarytmiske adrenergika.

Ved vekkingsforsøk etter ett døgn fikk pasienten residiv av polymorf ventrikkeltakykardi og ventrikkelflimmer. Man fortsatte med respiratorbehandlingen, og det var behov for høye doser sedative medikamenter. Dette førte igjen til blodtrykksfall og behov for inotrop støtte. Det var lite ønskelig, da denne typen medikamenter gir adrenerg stimulering, som kan trigge arytmier.

De neste fem døgn ble det ikke registrert noen arytmier, og det ble besluttet å lette på sedasjonen på nytt. Det gjorde imidlertid at pasienten igjen gikk inn $i$ en fase med elek-

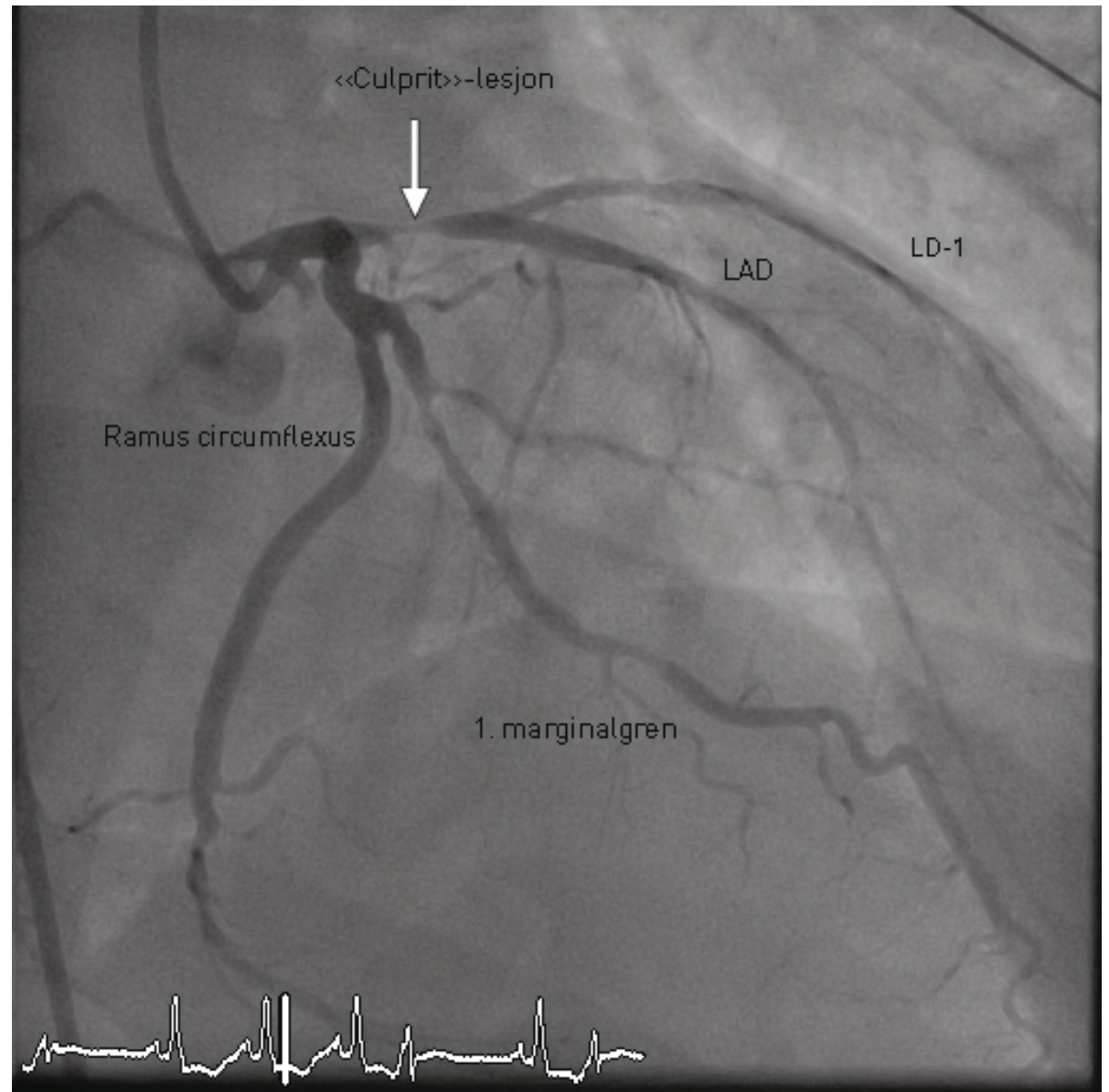

Figur 1 Koronarangiografimed fremstilling avvenstre koronararterie. «Culprit»-lesjonen proksimalt ifremre nedadstigende gren av venstre koronararterie (left anterior descending artery, $L A D$ ) er markert med pil. $L D-1=$ første diagonalgren

trisk storm, hvor rytmen vekslet mellom sinusrytme, polymorf ventrikkeltakykardi og ventrikkelflimmer. Det var da behov for 30 elektrostøt $i$ løpet av en halv time.

Beregning av QT-tid hører med til tolking av EKG, spesielt gjelder det hos pasienter med uavklart synkope eller der man har mistanke om arytmi. Lang QT-tid er tegn på forsinket repolarisering og gir ustabile elektriske forhold i myokard. Hos menn er lang QT-tid definert som korrigert QT-tid (QTc) $>450 \mathrm{~ms}$. Årsaken kan være ervervet eller genetisk betinget.

Lang QT-tid innebærer økt risiko for malign arytmi, som polymorf ventrikkeltakykardi. Ved lang QT-tid må derfor medikamenter som gir forlenget QT-tid seponeres. Listen over slike medikamenter er lang og kan finnes flere steder (8). Amiodaron er et slikt. Dersom årsaken til polymorf ventrikkeltakykardi er lang QT-tid, kalles denne torsades de pointes-takykardi.

Korrigert QT-tid hos denne pasienten var normal ved innleggelsen. Den økte imidler- tid under oppholdet og passerte 500 ms etter ti dagers behandling med amiodaron. Man valgte da å seponere medikamentet av frykt for at det kunne bidra til økt arytmitendens. Det ble i stedet startet opp med lidokaininfusjon. Behandling med betablokker og magnesium ble opprettholdt.

Jervell og Lange-Nilsens syndrom er en medfødt arvelig lidelse der pasienten både er døv og har lang QT-tid (9). Ettersom vår pasient var døv, kunne dette vært en aktuell diagnose. Imidlertid viste det seg at døvheten hos pasienten var en følge av meningitt i barneårene.

Etter det andre vekkingsforsøket ble pasienten sedert for tredje gang. Han fikk behandling med betabokker og magnesium og var bradykard med en puls på 40-50 slag/min (fig 2).

Noen ganger kan bradykardi utløse polymorf ventrikulær arytmi. Dette kan skje både med og uten QT-tidforlengelse. En pacemakerindusert rytme, litt raskere enn grunnrytmen, kunne teoretisk ha minsket arytmitendensen. 


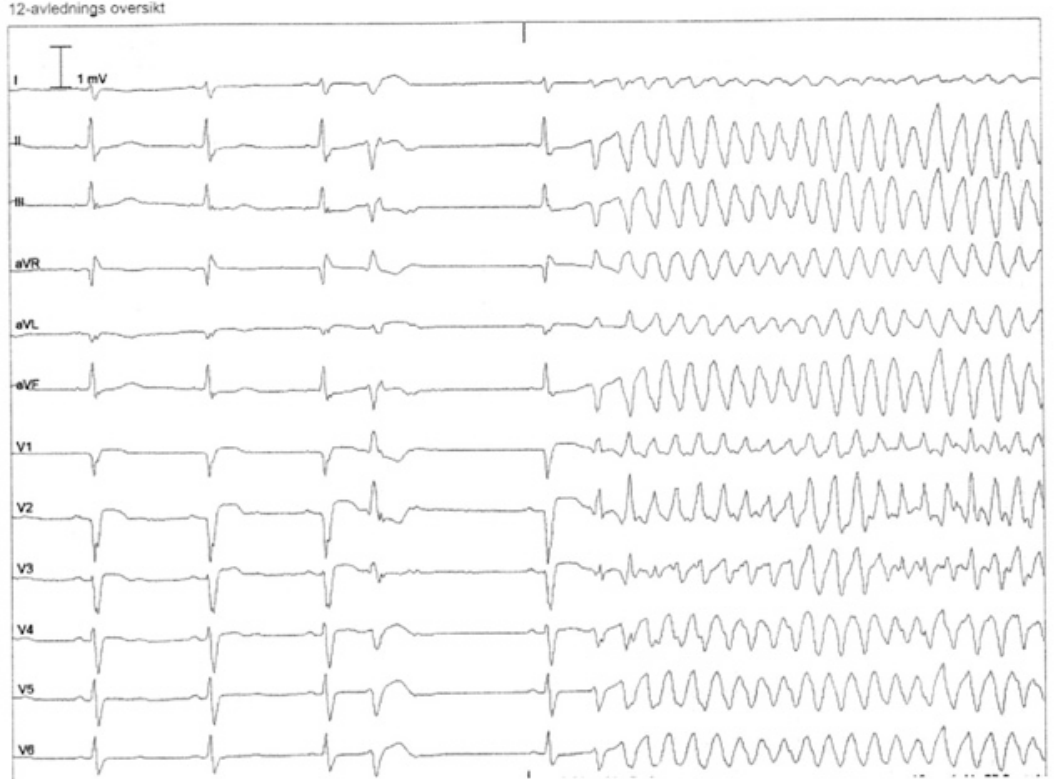

Figur 2 EKG viser to normalslag etterfulgt av en ventrikulær ekstrasystole med kort koblingsinervall. Etter dette oppstår en pause før et nytt normalslag med etterfølgende ventrikulær ekstrasystole, som induserer polymorf ventrikkeltakykardi. Normalslagene har QS-mønster i v1-v2 som tegn på forveggsinfarkt. Bestående ST-hevning er tegn på vedvarende iskemi eller eventuelt begynnende aneurisme

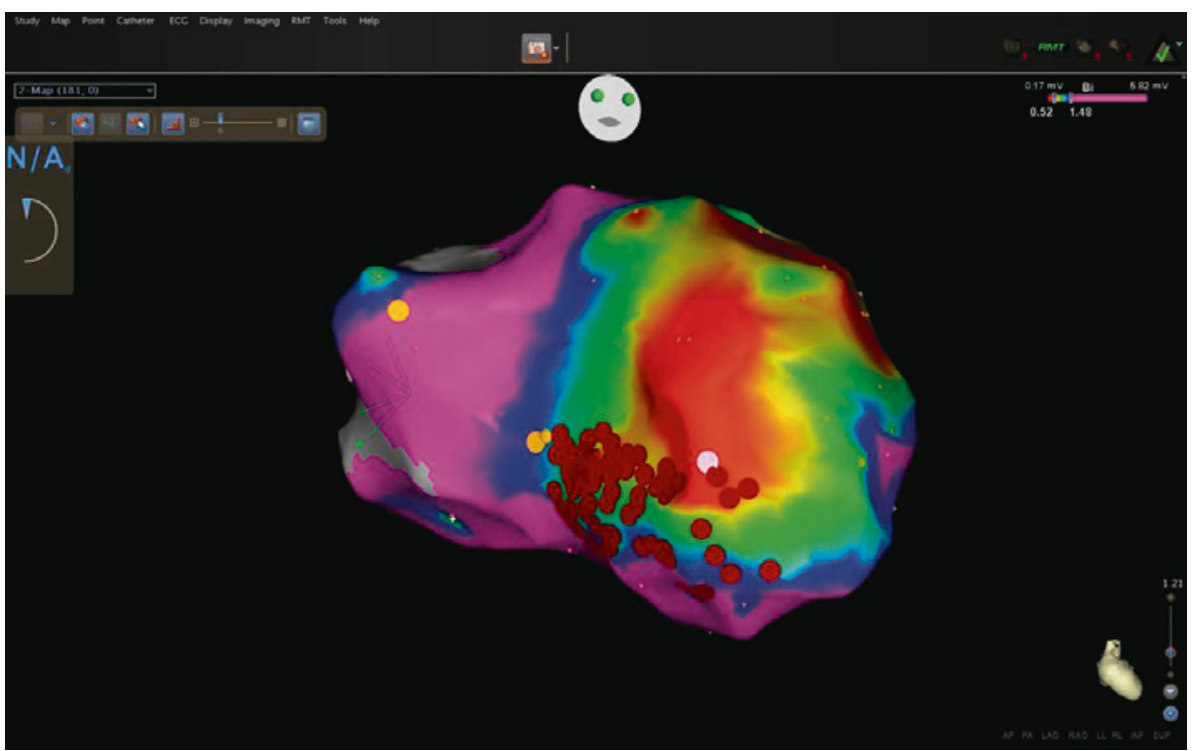

Figur 3 En tredimensjonal elektroanatomisk modell av venstre ventrikkel sett fra apeks. Fargene indikerer viabilitet, der rød farge er forenlig med arrvev og fiolett er normalt myokard. De mørkerøde punktene markerer gjennomførte ablasjonspunkter i randsonen av det anteroseptale infarktorådet

Vi vurderte innleggelse av temporær pacemaker for å ha muligheten til å holde en høy basalfrekvens, da dette kan være effektiv behandling av bradykardiutløst ventrikkeltakykardi. Pasienten var imidlertid så sensitiv for manipulasjon at det ble ansett som lite gunstig med pacemakerledning.

Pasienten hadde restskader $i$ koronararteriene, og for å redusere muligheten for at arytmiene ble utløst av iskemi ble det seks dager etter innkomst gjort perkutan koronar intervensjon av de gjenværende stenosene.

Til tross for dette var pasienten fortsatt svært ustabil rytmemessig, med residiverende ventrikkelflimmer, og han hadde behov for elektrokonvertering flere ganger per minutt. Samtlige episoder med ventrikkelflimmer ble utløst av spontane ventrikulære ekstrasystoler med lik morfologi.

Tidlig koblede ventrikulære ekstrasystoler i det initiale forløpet av et infarkt er en kjent utløsende mekanisme for polymorf ventrikkeltakykardi og ventrikkelflimmer $(10,11)$. Ekstrasystolene har vist seg å komme fra purkinjefibre i randsonen mellom infarsert og friskt myokard $(10,12)$. Purkinjefibre ligger subendokardialt, og de antas å være mer resistente mot iskemi enn vanlig myokard. Man antar at noe av perfusjonen skjer via diffusjon av endokavitært blod og at disse cellene således trolig ikke er like avhengige av koronarsirkulasjonen (13).

Delvis overlevende purkinjeceller i randsonen av et infarkt kan ha unormal intracellulær kalsiumregulering, noe som forårsaker sene etterdepolariseringer, spontan ekstrasystoli og arytmi. Kombinasjonen ustabil cellemembran og trigget automatisme vil derfor kunne gi ventrikulære ekstrasystoler som setter i gang reentrykretser $\mathrm{i}$ delvis overlevende myokard $\mathrm{i}$ randsonen av infarktet. Kretsene kan være små og ustabile og ha høy frekvens. Dette manifesteres som polymorf ventrikkeltakykardi og ventrikkeflimmer og kunne forklare vår pasients arytmier.

Pasienten hadde fortsatt elektrisk storm, og det var manglende respons på både medikamenter, revaskularisering og sedasjon. Man valgte derfor å forsøke kateterbasert ablasjonsbehandling $i$ håp om å oppheve den elektriske stormen.

Diagnostiske elektrodekatetre ble lagt fra v. femoralis til høyre ventrikkels apeks og til sinus coronarius. Via en transseptal lang styrbar hylse gjennom atrieseptum og mitralostiet ble et ablasjonskateter lagt til venstre ventrikkel for kartlegging (mapping) og ablasjon. Det ble brukt et fjernstyrt magnetisk navigasjonssystem for styring av ablasjonskateteret. Venstre ventrikkels endokard ble vist ved hjelp av et tredimensjonalt elektroanatomisk kartleggingssystem. Under prosedyren hadde pasienten flere hundre episoder med ventrikkelflimmer med behov for elektrokonvertering, men han var hemodynamisk stabil mellom episodene.

Det ble lokalisert et infarktområde anteroseptalt. Utgangspunktet for de ventrikulære ekstrasystolene som startet ventrikkelarytmiene ble funnet $i$ randsonen av infartktområdet, tilsvarende stedet for fremre fasciegren. Det ble sett et skarpt purkinjesignal 50 ms før de ventrikulære ekstrasystolene, og ved rytmeregulering (pacing) på dette stedet utløste man QRS-komplekser med identisk morfologi som de spontane ekstrasystolene. Radiofrekvensablasjon $i$ dette området fjernet de ventrikulære ekstrasystolene. Rytmen ble umiddelbart stabilisert, med vedvarende sinusrytme.

Radiofrekvensablasjon av purkinjefibrene som utløser ventrikulære ekstrasystoler kan 
oppheve elektrisk storm både ved idiopatisk ventrikkelflimmer og etter hjerteinfarkt (14, 15). Ved ablasjonsbehandling av ventrikkelarytmier gjør man først anatomisk og elektrisk kartlegging (mapping) av endokard og eventuelt av epikard (fig 3). Kartlegging av endokard i venstre ventrikkel kan foregå både ved retrograd tilgang av ablasjonskateteret via aorta og ved transseptal tilgang.

Et avansert lokaliseringssystem brukes for kateternavigasjon og for å lage en tredimensjonal elektroanatomisk modell av venstre ventrikkels endokard. Man foretar en nøye kartlegging av arrområder, spesielt av randsonen mellom skadet og friskt vev. Ved elektrisk storm utløst av ventrikulære ekstrasystoler vil man spesielt lete etter utgangspunktet for ekstrasystolene i områder der man finner purkinjefibre.

De neste to døgn var det ingen episoder med ventrikkeltakykardi eller ventrikkelflimmer. Så fikk pasienten monomorfe ventrikulære ekstrasystoler med en annen morfologi enn ekstrasystolene som utløste arytmiene før ablasjon. På nytt startet en elektrisk storm med ventrikkelflimmer utløst av monomorfe ekstrasystoler. Den kommende uken måtte han elektrokonverteres 50-200 ganger per døgn, og han fikk store brannsår på brystet. Standardmattene med ledning til defibrillator måtte byttes etter 50 støt. Dette var en ny erfaring for oss. Pasienten utviklet etter hvert pneumoni og nyresvikt, dog uten behov for dialyse. I tillegg var det et lett fall i hemoglobinnivå, uten sikker årsak.

Ni dager etter ablasjon hadde man fortsatt ikke rytmekontroll og besluttet derfor å utføre et nytt ablasjonsforsøk. Bruk av hjertelunge-maskin lekstrakorporeal membranoksygenering, ECMOl for å sikre sirkulasjonen under prosedyren ble vurdert, men dette ble ikke gjort.

Med ekstrakorporeal membranoksygenering vil perfusjon av alle organer opprettholdes uansett hjertefunksjon, da man med en maskin sørger for adekvat sirkulasjon med oksygenert blod. På grunn av magnetfeltet som omgir navigasjonssystemet for ablasjonsbehandling var imidlertid dette vanskelig å gjennomføre.

Etter ny, omfattende kartlegging ble utgangspunktet for de utløsende monomorfe ventrikulære ekstrasystolene funnet $i$ infarktets randområde, tilsvarende bakre fasciegren. Også her var det tydelige purkinjesignal 50 ms før ekstrasystolen, og rytmeregulering ga identisk QRS-morfologi. I forbindelse med prosedyren var det behov for en rekke elektrokonverteringer. Etter ablasjon opphørte ekstrasystolene og rytmen stabiliserte seg i 5-6 timer, men den påfølgende natten var det behov for ytterligere 32 elektrokonverteringer mot ventrikkelflimmer. Grunnrytmen var da langsom sinusrytme med ventrikulære ekstrasystoler i bigemini. Amidaronbehandlingen ble startet opp igjen, fem dager etter seponering, og pasienten beholdt en langsom sinusrytme. De neste dagene var det enkelte spredte ekstrasystoler, men ingen flere episoder med ventrikkeltakykardi eller ventrikkelflimmer.

Det ble imidlertid komplikasjoner i forbindelse med trakeostomien, som førte til blødninger. Koagler førte til obstruksjon i luftveiene og behov for økt respiratortrykk, og det ble intervenert med bronkoskopi og lokal kirurgi. Det var planlagt et nytt vekkingsforsøk, men før det fikk pasienten akutt melena og ble hemodynamisk ustabil. Man antok at stressulcus var årsak til blødningen. Grunnet nylige implanterte stenter sto han på kontinuerlig dobbelt platehemmende behandling med acetylsalisylsyre og klopidogrel, og dette ga økt blødningsrisiko. Vurderingen var at pasienten på dette tidspunkt ikke var kandidat for operasjon eller endoskopisk undersøkelse. Han døde noen timer etter at blødningen startet.

\section{Diskusjon}

Pasienten kom inn i sykehus med et hjerteinfarkt, som ble behandlet etter gjeldende retningslinjer. Forløpet ble komplisert med alvorlig og terapiresistent ventrikulær arytmi. På tross av intensiv farmakologisk behandling og bruk av flere moderne og høyteknologiske behandlingsmetoder døde han etter at han var blitt elektrokonvertert over 2000 ganger i løpet av to uker.

Elektrisk storm er en livstruende tilstand som kan være vanskelig å behandle. Denne kasuistikken illustrerer at kateterbasert ablasjonsbehandling kan være en aktuell strategi når man ikke får kontroll over situasjonen med revaskularisering, betablokker, antiarytmika og sedering. Hvis konvensjonell behandling ikke er effektivt, bør ablasjonsbehandling antakelig gjøres så tidlig som mulig. Flere observasjonsstudier viser at dette kan være en livreddende prosedyre, med gode langtidsresultater $(16,17)$.

I ettertid kan man spørre om ikke ablasjonsbehandling burde vært utført tidligere hos vår pasient. Med ablasjon av de ventrikulære ekstrasystolene som utløste ventrikkelflimmer fikk man kontroll på rytmen, men pasienten døde som direkte følge av en større gastrointestinal blødning. Det er også uklart hvordan den cerebrale funksjonen ville ha vært etter så mange episoder med forbigående sirkulasjonsstans. Ekstrakorporeal membranoksygenering kunne ha vært aktuelt for å sikre den cerebrale sirkulasjonen i intensivsituasjonen (6). Dersom man ikke hadde oppnådd rytmekontroll med ablasjon, kunne slik behandling ytterste konsekvens vært en bro til hjertetransplantasjon (6).

Om man går til starten av denne sykehistorien, er et viktig budskap at pasienten hadde klare symptomer på ustabil koronarsykdom i flere dager før han ble innlagt. Antakelig var forsinket revaskularisering i dette tilfellet en viktig faktor for utvikling av et arytmogent substrat. Pasienter med symptomer på ustabil koronarsykdom skal legges inn i sykehus for medikamentell behandling, tidlig invasiv utredning og revaskularisering.

Historien illustrerer bruk av avansert og høyteknologisk behandling som kun er tilgjengelig på noen ytterst få sykehus i Norge. Vi har også omtalt muligheten for bruk av ekstrakorporeal membranoksygenering i situasjoner hvor pasientens hjertefunksjon er så dårlig at avansert understøttende behandling er det eneste livreddende. Kasuistikken illustrerer hvordan moderne og sentralisert høyteknologisk behandling kan komme til anvendelse hos et mindre utvalg av pasienter med kompliserte forløp etter hjerteinfarkt. Dette stiller oss overfor en del utfordringer når det gjelder seleksjon og retten til lik behandling uavhengig av bosted.

Pasientens pårørende har gitt samtykke til at artikkelen blir publisert.

\section{Stian Ross (f. 1974)}

er spesialist i hjertesykdommer. Han er nå overlege ved Hjerteseksjonen, Medisinsk avdeling, Sykehuset Østfold.

Forfatter har fylt ut ICMJE-skjemaet og oppgir ingen interessekonflikter.

\section{Ole Rossvoll (f. 1955)}

er overlege og spesialist i hjertesykdommer Hans hovedarbeidsfelt er elektrofysiologi og ablasjonsbehandling av hjerterytmeforstyrrelser. Forfatter har fylt ut ICMJE-skjemaet og oppgir følgende interessekonflikter: Han er rådsmedlem i St. Jude og har mottatt reisestøtte/foredragshonorar fra St. Jude, Johnson \& Johnson og Stereotaxis.

\section{Marcel Moufack (f. 1967)}

er spesialist i hjertesykdommer, med hovedarbeidsfelt elektrofysiologi, og lektor ved Norges teknisk-naturvitenskapelige universitet. Forfatter har fylt ut ICMJE-skjemaet og oppgir ingen interessekonflikter.

\section{Rune Wiseth (f. 1954)}

er spesialist i hjertesykdommer, klinikksjef og professor i hjertesykdommer. Hans hovedarbeidsfelt er invasiv kardiologi.

Forfatter har fylt ut ICMJE-skjemaet og oppgir ingen interessekonflikter. 


\section{Litteratur}

1. Steg PG, James SK, Atar D et al. ESC Guidelines for the management of acute myocardial infarction in patients presenting with ST-segment elevation. Eur Heart J 2012; 33: 2569-619.

2. Bøhmer E, Hoffmann P, Abdelnoor M et al. Efficacy and safety of immediate angioplasty versus ischemia-guided management after thrombolysis in acute myocardial infarction in areas with very long transfer distances results of the NORDISTEM (NORwegian study on Dlstrict treatment of STelevation myocardial infarction]. J Am Coll Cardiol 2010; 55: 102-10.

3. Zipes DP, Camm AJ, Borggrefe M et al. ACC/AHA/ ESC 2006 guidelines for management of patients with ventricular arrhythmias and the prevention of sudden cardiac death: a report of the American College of Cardiology/American Heart Association Task Force and the European Society of Cardiology Committee for Practice Guidelines (Writing Committee to Develop Guidelines for Management of Patients With Ventricular Arrhythmias and the Prevention of Sudden Cardiac Death). J Am Coll Cardiol 2006; 48: e247-346

4. Issa ZF, Miller JM, Zipes DP. Clinical arrhythmology and electrophysiology: a companion to Braunwald's heart disease. 2. utg. Amsterdam: Elsevier 2012: 405

5. Bourke T, Vaseghi M, Michowitz Y et al. Neuraxial modulation for refractory ventricular arrhythmias: malue of thoracic epidura anesthesia and surgical left cardiac sympathetic denervation. Circulation 2010: 121: 2255-62.

6. Fux T, Svenarud P, Grinnemo K-H et al. Extracorporeal membrane oxygenation as a rescue of ntractable ventricular fibrillation and bridge to heart transplantation. Eur J Heart Fail 2010: 12: $301-4$

7. Fotopoulos GD, Mason MJ, Walker S et al. Stabilisation of medically refractory ventricular arrhythmia by intra-aortic balloon counterpulsation. Heart 1999: 82: 96-100.

8. Drug Lists by Risk Groups. www.azcert.org/ medical-pros/drug-lists/drug-lists.cfm (27.1.2013)

9. Jervell A, Lange-Nielsen F. Congenital deafmutism, functional heart disease with prolongation of the Q-T interval and sudden death. Am Heart J 1957; 54: 59-68.

10. Marrouche NF, Verma A, Wazni $O$ et al. Mode of initiation and ablation of ventricular fibrillation storms in patients with ischemic cardiomyopathy. J Am Coll Cardiol 2004; 43: 1715-20.

11. Maggioni AP, Zuanetti G. Franzosi MG et al. Prevalence and prognostic significance of ventricular arrhythmias after acute myocardial infarction in the fibrinolytic era. GISSI-2 results. Circulation 1993; 87: 312-22
12. Nogami A. Purkinje-related arrhythmias part it: polymorphic ventricular tachycardia and ventricular fibrillation. Pacing Clin Electrophysiol 2011: 34 $1034-49$

13. Friedman PL, Stewart JR, Fenoglio JJ jr. et al. Survival of subendocardial Purkinje fibers after extensive myocardial infarction in dogs. Circ Res 1973; 33: 597-611.

14. Huang SK, Wood MA. Catheter ablation of cardiac arrhythmias. 2. utg. New York: Saunders, 2010: 507

15. Bänsch D, Oyang F, Antz M et al. Successful catheter ablation of electrical storm after myocardial infarction. Circulation 2003; 108: $3011-6$.

16. Carbucicchio C, Santamaria M, Trevisi N et al. Catheter ablation for the treatment of electrical storm in patients with implantable cardioverterdefibrillators: short- and long-term outcomes in a prospective single-center study. Circulation 2008; 117: 462-9.

17. Kozeluhova M, Peichl P. Cihak R et al. Catheter ablation of electrical storm in patients with structural heart disease. Europace 2011; 13: 109-13.

Mottatt 10.8. 2012, første revisjon innsendt 16.12 2012, godkjent 23.5. 2013. Medisinsk redaktør Merete Kile Holtermann.

\section{Kommentar}

\section{Kardiologens mareritt}

Elektrisk storm er et av kardiologenes verste mareritt. Pasientene må gang på gang sjokkes ut av ventrikkelflimmer, og det er vanskelig å vite hva man skal gjøre. Stian Ross og medarbeidere rapporterer om et lærerikt tilfelle.

Inntil midten av 1990-årene ble det brukt mer antiarytmika enn man bruker nå. Medisinene ga proarytmier, og seponering var viktigste og vanligste behandling ved elektrisk storm. I dag er det å redusere iskemi (revaskularisering og betablokade), redusere veggstrekket (optimal sviktbehandling) og korrigere acidose og elektrolyttforstyrrelser (især hypokalemi) det grunnleggende. Så tyr man til infusjon av magnesium, som reduserer kalsiumoverbelastningen av cellene (1), og til amiodaron. Denne prosedyren ble fulgt hos den aktuelle pasienten, men det trengtes i tillegg sterk sedering. Da det kom tilbakefall etter oppvåkningen, var det fortsatt noen terapimuligheter:

Én mulighet er rask ventrikkelpacing, som ofte er effektivt (2). Økt frekvens gir kortere aksjonspotensialer (mindre kalsiumoverbelastning) og kortere diastoler, med tilsvarende kortere eksiterbar glipe hvor en ekstrasystole kan utløse arytmi. Dette er særlig virksomt når arytmien, som her, utløses av en pause fulgt av en tidlig koblet ventrikulær ekstrasystole. Min erfaring er at man må starte med rask pacing (120-130 slag/min), lirke ned frekvensen til som regel rett under $100 \mathrm{slag} / \mathrm{min}$ og holde den der en dag eller to. Forfatterne overveide denne muligheten, men fant at pasienten var for ustabil for slik intervensjon. Ventrikkelpacing vil gi dårligere hemodynamikk, og pacemakerkateteret kan irritere ventrikkelen. Imidlertid er vår erfaring at rask atriepacing, som gir bedre hjertefunksjon, også kan fungere godt.

En annen mulighet er å seponere mulige proarytmiske medikamenter. Amiodaron gir sjelden proarytmi, men det forekommer (3). Da må man seponere og eventuelt gi annet (uregistrert) antiarytmikum, f.eks. bretylium (4). Her vet vi ikke om dette var tilfellet hos pasienten.

En tredje mulighet er kateterablasjon av mistenkt arytmifokus. Forfatterne valgte dette alternativet, som krever et høyteknologisk arytmilaboratorium, hemodynamisk støttebehandling og en mer enn vanlig erfaren operatør. Det er en bragd at prosedyren lyktes teknisk - men dessverre hadde pasienten vært i hjertesvikt så lenge at livet ikke lenger sto til å redde.

Hvilken lærdom kan vi trekke av dette? Primærsykehus må, som i dette tilfellet, raskt overflytte slike pasienter til regionsykehus. Behandlingsalgoritmen bør følges med kort observasjonstid på hvert trinn, slik at pasienten ikke blir utslitt. En sjelden gang kan kateterablasjon brukes som ultimum refugium. En pasient som har overlevd en elektrisk storm, bør få undersøkt genbærerstatus for mutasjoner som gir lang QT-tid, selv om utgangs-EKG skulle være normalt (5).

\section{Knut Gjesdal}

knut.gjesdal@medisin.uio.no

Hjertemedisinsk avdeling

Oslo universitetssykehus, Ullevå

Knut Gjesdal (f. 1944) er dr.med. og professor i kardiologi.

Forfatter har fylt ut ICMJE-skjemaet og oppgir følgende interessekonflikter: Han har mottatt foredragshonorar fra Astra-Zeneca, SanofiAventis og Meda.

\section{Litteratur}

1. Tzivoni D, Keren A, Cohen AM et al. Magnesium therapy for torsades de pointes. Am J Cardiol 1984; 53: 528-30

2. Sowton E, Leatham A, Carson P. The suppression of arrhythmias by artificial pacemaking. Lancet 1964: 2: 1098-100.

3. Hohnloser SH, Klingenheben T, Singh BN. Amiod arone-associated proarrhythmic effects. A review with special reference to torsade de pointes tachycardia. Ann Intern Med 1994; 121: 529-35.

4. Nakstad AR, Eek C, Aarhus D et al. Survival after prolonged resuscitation with 99 defibrillations due to Torsade De Pointes cardiac electrical storm: a case report. Scand J Trauma Resusc Emerg Med 2010; 18: 7

5. Lehtonen A, Fodstad $\mathrm{H}$, Laitinen-Forsblom $\mathrm{P}$ et al. Further evidence of inherited long QT syndrome gene mutations in antiarrhythmic drug-associated torsades de pointes. Heart Rhythm 2007; 4: 603-7.

Mottatt 20.6. 2013 og godkjent 20.6. 2013. Medisinsk redaktør Merete Kile Holtermann. 